\title{
Omkring en fæstnings fald
}

\section{A. F. Tscherning og planerne om en undsætningsekspedition til Rendsborg 1848}

\section{Af Hans Neerbek}

Tidligt om morgenen den 24. marts 1848 blev fæstningen Rendsborg overrumplet af prinsen af Nør og hans slesvig-holstenske allierede. Det danske militær var uforberedt, selv om der længe havde været optræk til uro, og der havde været planer om en undsætning af Rendsborg kort forinden. Fhv. studielektor Hans Neerbek har undersøgt historien om, hvorfor undsætningen blev opgivet og spørger, hvordan det ville være gået, hvis Rendsborg havde fået den besætning, som først var besluttet.

\section{Uro i februar}

Året 1848 var lige fra begyndelsen en urolig periode både for Danmark og Europa.

Den danske konge Christian 8.'s mål havde i de foregående år været at bevare helstaten, dvs. Danmark, Slesvig og Holsten, og det havde politisk bragt ham ind på en siksakkurs over for hertugdømmerne, hvor også familieforhold kom til at spille ind - $\mathrm{i}$ fire år havde hans svoger, prinsen af Nør været general og statholder i hertugdømmerne - indtil han i protest gik af, fordi han ligesom sin ældre bror, hertugen af Augustenborg, indædt gik ind for SlesvigHolstens uafhængighed og uadskillelighed.

Men i selve kongeriget voksede stemningen for et Ejderdanmark, dvs. Danmark og Slesvig nøjere forbundet og samtidig ønsket om en fri forfatning. Det var disse problemer Frederik 7. havde arvet, da hans far døde den 20. januar.

Samtidig var overalt i Europa borgernes selvstændighedsfølelse vokset stærkt, og dermed var der opståt et stigende krav om medbestemmelse i landenes styreform.

I slutningen af februar havde Paris' befolkning vendt sig mod »borgerkongen«, som gik af og siden rejste bort.

Men endnu sad i Kongens Kiøbenhavn de gamle gehejmestatsministre og styrede i statsrådet under devisen "Vi alene vide».

Allerede $i$ begyndelsen af marts var en lille inderkreds klar over, at en krig var forestående. "Den virkelige fare», skrev afdanket artillerikaptajn Tscherning d. 8. marts $1848 \mathrm{i}$ "Fædrelandet«, "kommer mod syd, fra hertugdømmerne«,' og det havde han en særlig grund til at vide. For nede i det 
sønderjyske sad oberst Chr. Rømeling. Han havde som 27 årig i 1813 været med i slaget ved Sehested, han havde været ansat under prinsen af Nør, da denne var kommanderende general, og gennem de seneste år var han blevet mere og mere besat af en tvangstanke: "Når slesvigholstenerne gør oprør, så indtager de først fæstningen Rendsborg . $^{2}$

I brev efter brev til generaladjudanten $\mathrm{C}$. Ewald, der havde den gamle konges øre, havde han bønfaldt om 5000 mand danske tropper til at besætte Rendsborg. Hans overordnede, general v. Lützow, havde endda sagt, at prinsen af Nør blot behøvede at møde op i egen person for at tage fæstningen med dens ammunitions- og våbenbeholdninger og landets hovedkasse. Ganske vist mente Rømeling, at det var noget overdrevet, men man kunne jo aldrig vide?

Han syntes indtil nu at have råbt $\mathrm{i}$ ørkenen uden at få svar. Men munden på den, han henvendte sig til, var ikke lukket. Krigsmænd som Tscherning krigsminister fra d. 22. marts - kendte godt nok ad omveje Rømelings tanker. ${ }^{3}$

Scenen er sen aften kort før midten af måneden på grosserer Suhrs kontor i København, hvor vennen Tscherning er til stede. Etatsråd Bang, som har

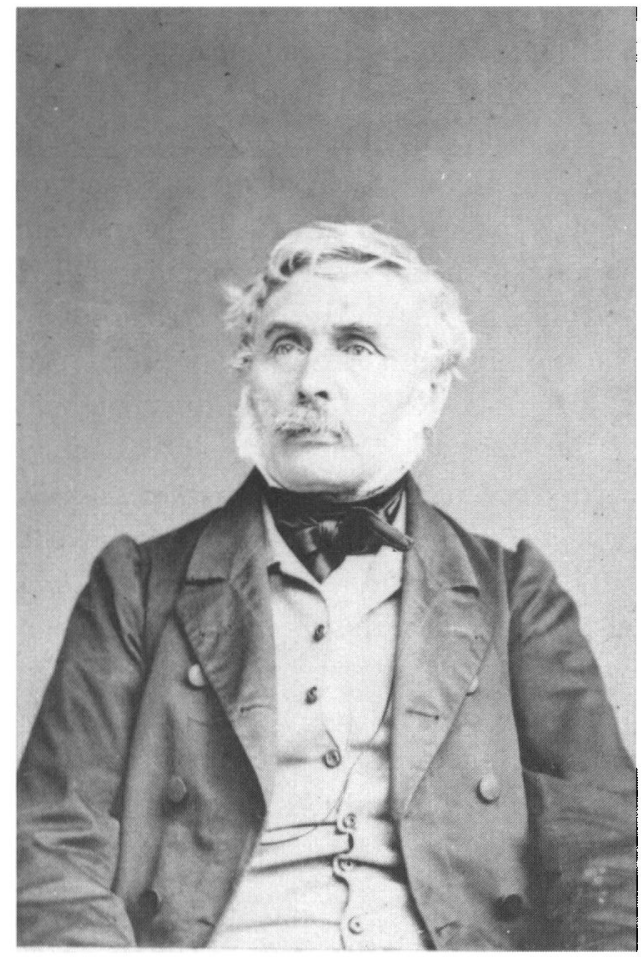

Oberst A.F.Tscherning (1795-1874), krigsminister $i$ 1848, fotograferet af M.Unna, Strieglers atelier $i$ Kubenhavn. Fotografi $i$ Dansk Centralbibliotek for Sydslesvig. 
mere end et ben indenfor i regeringskredse, kan berette, at »man«, dvs. generaladjudant Schøller, mener, der vil'gå mindst 6 uger for at få sendt nogle tusinde mand til hertugdømmerne.

Tscherning: "Hvis man ville give mig fuldmagt, vil jeg indestå for, at der $\mathrm{i}$ løbet af få dage ville være et par tusinde mand bragt til Kiel og Rendsborg«.

Bang: »Vogt Dem, at De ikke bliver sat på prøve! $\aleph^{4}$

\section{Møderne i Rendsborg og København}

Og så springer stikflammer fra februarrevolutionens store bål i Paris ud over det ganske fastland. Den 18. marts er en lille gnist nået op til Rendsborg.

Slesvig-holstenerne får indkaldt til et ulovligt- "forenet « stændermøde, hvor man vedtager at sende en deputation til kongen i København med krav om fællesforfatning med mere. ${ }^{5}$

Men hvis det ulmede i den værtshussal, hvor stændermedlemmer holdt til, så slog der formelig luer i vejret i det nærliggende skuespilhus. Her er studenter, soldater og andet godtfolk mødt op, og man vedtager det ene krav efter det andet; under særlig jubel, at Rendsborg skal gøres til en tysk forbundsfæstning! $!^{6}$

Endnu er de to hovedaktører, de augustenborgske brødre, ikke trådt åbent frem på scenen. Men prinsen af Nør sender allerede dagen efter den danske konge et brev, hvor han nærmest forlanger at blive udnævnt til general og statholder $\mathrm{i}$ hertugdømmerne (igen), og straks efter får han besøg af sin ældre bror, som hemmeligt er på vej til Berlin. Denne får den fremfusende lillebror til at love ikke at foretage sig noget overilet, mens han selv er bortrejst. ${ }^{7}$

Næste akt er i København. Der er først et artigt lille forspil i statsrådet, hvor man efter at have erfaret, at man ikke kan stole på tropperne i hertugdømmerne snakker frem og tilbage om indkaldelser og ender med d. 20. marts at befale den kommanderende general at forlægge sit hovedkvarter fra Slesvig by til Rendsborg.

Anderledes ude i byen. Da man her hører om Rendsborgmødet, indkaldes til møde i "Casino«, hvor det om aftenen d. 20. besluttes at gå til kongen for at bede om en fri forfatning og en afvisning af slesvigholstenernes krav. Det lykkes dog Tscherning at skaffe majestæten nattero ved at opfordre forsamlingens uroligste hoveder til at vente til næste formiddag.

Dagen derpå d. 21. gik så folketoget til Christiansborg. "Alt foregik i den største rolighed, og ordenen blev ikke i mindste måde forstyrret, « skrev den konservative "Berlinger«. Kong Frederik kunne da også straks udtale, at han allerede havde afskediget sit ministerium og ville gå ind på alle ønsker og 
krav. Så nu gjaldt det bare om at få en ny regering, som kunne svare den slesvigholstenske deputation, som i øvrigt samme dag var rejst fra Kiel.

Næste dag havde man et slidsomt arbejde med at få sammensat en ny regering, men da man først havde fået overtalt den gamle grev $\mathrm{A}$. W. Moltke til at træde i spidsen, gik det også nogenlunde godt, indtil der blev tale om Tscherning som krigsminister. "De høje herrer deroppe tog hellere Satan end mig, « sagde han samme dag til sin kone, ${ }^{8}$ og den kongelige rådgiver Bardenfleth skal da også have sagt: "Det er ikke Hans Majestæts hensigt at synke så dybt! «" Tscherning havde da også forlangt nærmest diktatorisk magt, men der var ingen vej udenom, og hen på formiddagen $\mathrm{d}$. 22 . blev han kaldt op på slottet.

Mens han ventede $\mathrm{i}$ forværelset, mødte han en række gamle officerskammerater, og samtalen kom naturligt til at dreje sig om en undsætning af Rendsborg. Da Tscherning indvendte, at man jo ikke kunne tage alle kadrene (stamafdelingerne) fra København, svarede kaptajn Harbou, at man bare kunne stikke hele styrken af menige ind i 3 bataljoner med 10-13 særlige kompagnier.

Ingen var i tvivl om, at det skulle ske søværts, men mens kaptajn Dinesen mente, at det skulle ske over Kiel, så at kanalen kunne dække venstre flanke, foretrak Harbou Eckernførde, hvor marchen ville blive kortere, og hvor en eventuel større modstand kunne ydes ved Schiernauerpasset.

Tscherning får sagt, at han vil forbeholde sig Harbou "for den kommanderende general«, og Dinesen skal have batteriet. Læssøe nævnes som stabschef, kaptajn Neergaard som særlig terrænkyndig, og det samme gælder kaptajn Clode du Plat. Allesammen er de omkring 40 år, og næsten alle har krigserfaring fra frivillig deltagelse $i$ udenlandske slag.

Mens nu Tscherning d. 22. gik ind til statsrådsmøde, ilede Harbou ud i byen for at tale med Læssøe og få hans samtykke til planerne. ${ }^{10}$

Hvis Harbou og de andre havde kunnet følge handlingsgangen i statsrådsmødet, ville de mildest talt være blevet noget forbløffede; selv om statsrådet fra den dag af ikke længere var "geheime«, er det dog først i vore dage, vi kan læse referaterne af forhandlingerne."

Ikke med ét eneste ord foreslår den nybagte krigsminister den undsætningsekspedition, man lige har talt om. Tværtimod. "Skulle man søge at henholde tiden, « siger han, "da burde det ei være for at ruste sig, men for at give den herskende exaltation tid til at lægge sig.« I øvrigt spørger han, militærmanden, som har skubbet kongen selv til side som øverstkommanderende, de gamle, civile statsråder, om de mener, at militære operationer for tiden vil være skadelige eller gavnlige! Da de efter forventning fraråder dem, beder han, om man ikke kan lade bladene omtale standsningen af dem, "da det navnligen 
Netop den 24.marts 1848 - den dag, Rendsborg blev overrumplet - afbildede det satiriske blad "Corsaren" Tscherning (til hojre) $i$ kamp med en modstander, der skulle symbolisere en slesvigholstener. Bladet pastod, at Tscherning havde erklaret at ville kaste slesvigholstenerne til jorden!

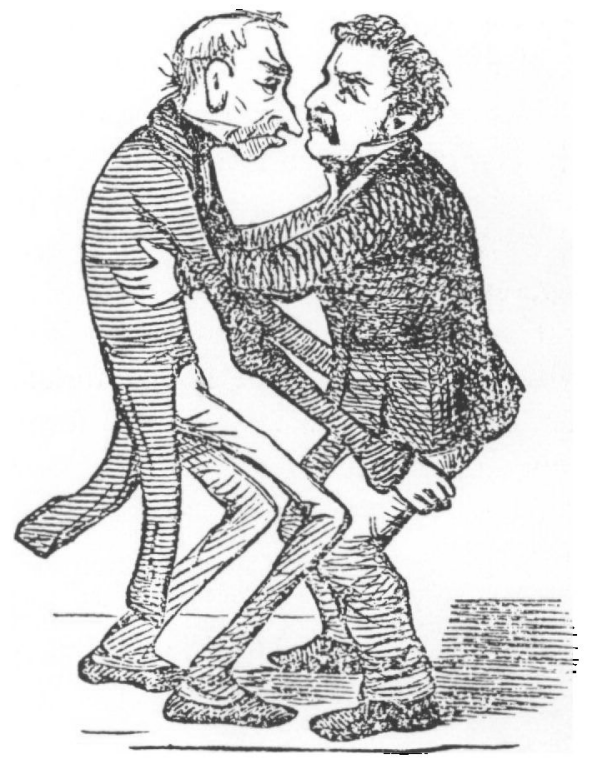

var ham væsentligt at have noget at støtte sig på imod den overvejende mængde, som trængte sig ind på ham for uopholdeligen at anvende magten«.

Midt $i$ alt dette bliver han af en af kongens adjudanter kaldt ud til Harbou, som efter at have fảet Læssøes tilslutning beder ham så hurtigt som muligt træffe sine dispositioner. Tscherning svarer, at der endnu ikke er truffet nogen bestemmelse, og han beder ham komme til sin bopæl senere på eftermiddagen.

»Da kom jeg også, « skriver Harbou, »jeg tror mellem 5 og 6« og fik nu den besked, at man ville afvente nærmere efterretning. "Og den bliver, « var mit svar, nat oprøret er udbrudt, Rendsborg faldet, og at De vil have at begynde en krig, der kan vare et par år.« "Nå, så er det Vorherres vilje, og så må det være det bedste, " var hans svar. ${ }^{12}$

Men Vorherre undte nu ikke kaptajn Tscherning fuldstændig nattero. "Ved midnat blev jeg vækket; det var kaptajn Dinesen af artilleriet, en af dem, der i dagens løb havde ivret mest for at få ekspeditionen afsendt til Eckernførde, han havde endnu ikke opgivet denne plan. Dampskibene, sagde han, havde damp oppe, og flere af tropperne var på rede hånd. Han bad og besvor mig tage følgerne af denne ekspedition på mig. Han var meget utrøstelig, næsten forbitret, da det ikke lykkedes ham at bringe mig til at gå ind på hans forslag. $\aleph^{13}$

Så endelig kunne den trætte minister vende sig om på sit grønne øre.

Selvsamme aften d. 22. marts sidder hertugen af Augustenborg på sit værelse 


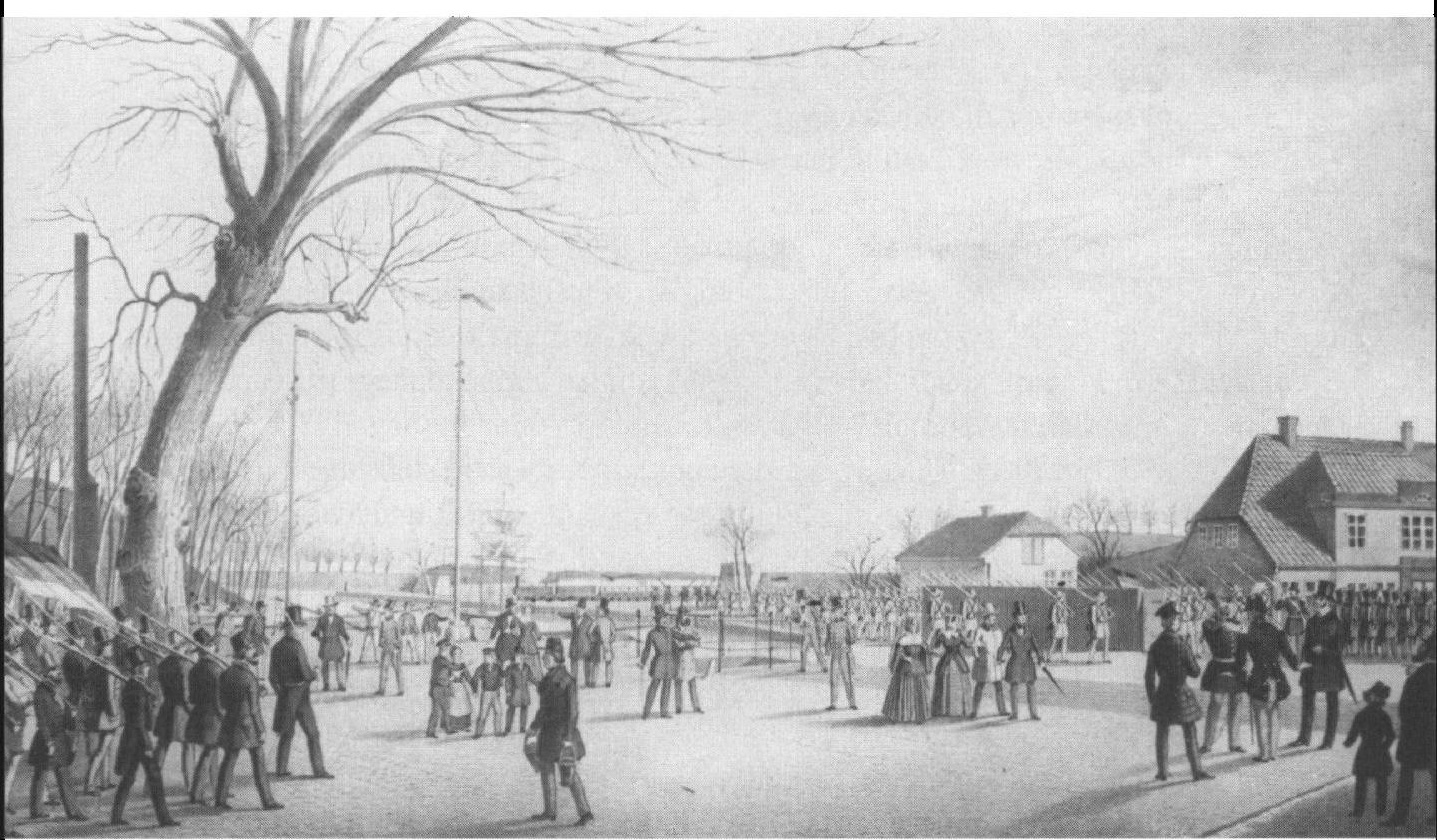

Rendsborgs overrumpling den 24.marts 1848 er segt anskueliggjort pd dette samtidige, farvelagte stik fra fastningsbyens Jungfernstieg. I baggrunden toget, som $\mathrm{kl}$. $9 \mathrm{om}$ morgenen bragte advokat Beseler og prinsen af Nor og hans folk 250 jagere fra Kiels garnison og 50 Kiel-borgere og studenter - til byen. Til venstre marcherer borgervabningen frem med oprorsfanen. Til hojre ses prinsen af Nor. advokat Beseler (med bakkenbarter) og bykommandanten.

Dansk Centralbibliotek for Sydslesvig.

på hotel Skt. Petersborg i Berlin. Hans fætter Valdemar, som har fulgt ham derhen, har ikke givet ham meget håb. Han er også selv bange for, skriver han i et brev hjem til sin kone, at der ikke er meget at opnå hos Prøjsen. Han havde ladet sig melde hos kongen lige efter sin ankomst, men ville først blive modtaget næste formiddag. Hvis det ikke lykkes ham at få støtte, vil han snarest muligt vende hjem igen. ${ }^{14}$

\section{Oprøret}

Om morgenen d. 23. var "Berlingske Tidende« for den foregående dag nået frem til Madam Esselbachs gastgivergård i Slesvig med beretning om begivenhederne i København d. 21., og advokat Beseler, en af de slesvigholstenske hovedmænd, havde straks begivet sig til Kiel og undervejs stævnet sine bunds- 
forvandte hertil. En af dem var prinsen af Nør, som omgående drog afsted med sin gamle generalsuniform i kufferten.

De mødtes alle på advokat Bargums værelse, og her dannedes en provisorisk regering, som i sin proklamation forkyndte, at den ville styre på "den ufri hertug «s vegne. ${ }^{15}$

Samtidig enedes man om, at prinsen af Nør skulle drage til Rendsborg for at overtage kommandoen over fæstningen, og prinsen selv forkyndte nu, at han faktisk havde skrevet et brev, som på forhånd skulle overrækkes general v. Lützow og kommandanten, oberst Seyffart, hvori han opfordrede dem til at overgive fæstningen til ham.

TABLEAU! En af de tilstedeværende, godsejer Hirschfeld, protesterede på det kraftigste. Alt ville være tabt, mente han, hvis man ikke kunne overrumple de ledende officerer, og han tilbød straks at ride til Rendsborg om natten for at træffe hemmelig aftale med de tysksindede på fæstningen. ${ }^{16}$

Derved blev det, men først efter midnat kunne han komme afsted, da beslutningen om regeringsdannelsen først skulle offentliggøres fra rådhuset.

I de små morgentimer d. 24. marts ruller Hirschfeld i sit tospand ind $\mathrm{i}$ Rendsborg, hvor alt ligger $i$ dyb søvn, kun en søvnig skildvagt går frem og tilbage ved porten.

Han får vækket en bekendt, som er direktør for jernbanen, og der bliver sørget for, at det kommende tog kan rulle helt ind til fæstningen ad en nyopført bro, så det ikke kan ses fra voldene. ${ }^{17}$

Omkring kl. 6 om morgenen er der blevet blæst generalmarch og ringet med kirkeklokkerne $\mathrm{i}$ Kiel, og folk er strømmet til rådhuset, hvor proklamationen er blevet oplæst for anden gang. Midt $\mathrm{i}$ det hele var dampskibet »Christian 8. « ankommet, og den gode danske kaptajn ombord var blevet noget forbløffet over at høre, at man troede, han havde danske tropper med. ${ }^{18}$

Imens var prinsen af Nør, uden at afvente om der skulle være noget svar på hans henvendelse til den danske konge, steget på toget på Kiels banegård med 2-300 mand, en del kun bevæbnede med knipler. Lidt over kl. 9 kan han gå over paradepladsen i Rendsborg fæstning, hilst med jubel af soldaterne og meddele general Lützow, at han nu har overtaget kommandoen. Til stabschefen sagde han: "Gamle Rømeling, De har jo allerede forlængst forudsagt, at det tilsidst ville komme så vidt! «"19

De to ældre herrer, Lützow og Rømeling, var ankommet til fastningen den foregående eftermiddag og havde først da fået en fornemmelse af, at man måske heller ikke kunne stole på de højere befalingsmænd. Nu var disse officerer med 1200 menige, våben, ammunition, uniformer og hovedkassen med flere millioner tilfaldet slesvigholstenerne - uden at et eneste skud var blevet løsnet i vrede! 
Fra Augustenborg slot skrev hertuginden på denne dag et brev til sin gemal; hun havde endnu intet hørt om oprøret i Kiel, - kun rygter om dannelsen af en ny regering i København. Hun sluttede sit brev med ordene: „Gid dog blot kongen af Prøjsen havde tid til at tale med dig, min englemand! $\varkappa^{20}$

Det havde kong Frederik Wilhelm 4. da heldigvis også, men han havde ikke villet gå med til at udstede nogen form for højtidelig proklamation, men kun svare med et åbent brev på en henvendelse, som hertugen havde måttet nedskrive på stående fod. Det hed heri, at kongen ville støtte hans sag, men kun diplomatisk og det endda med den karakteristiske tilføjelse: »Jeg håber $\mathrm{i}$ øvrigt, at ingen alvorlig fare truer den slesvigholstenske nationalitet!« Christian August var bestemt ikke tilfreds med denne formulering, men han måtte stille sig tilfreds med den. "Det har kostet mig møje nok at få kongen så langt!« sagde den prøjsiske udenrigsminister.

Da hertugen den næste dag var kommet til Hamburg, fik han at vide, hvad der var sket $\mathrm{i}$ mellemtiden, og hans første reaktion var udbruddet: "Den dumme dreng har fordærvet det hele for os! «"1

Den mening beholdt han nu ikke længe.

\section{Kunne undsætningsekspeditionen være gennemført med held?}

I det foregående er Harbous fremstilling brugt som grundlag for gengivelse af forhandlingerne på Christiansborg om undsætningsekspeditionen. Tschernings egen version er mindre explicit.

"Der fandtes forskellige andre mænd i forværelset, deriblandt daværende kaptajn Harbou, der var kommet fra Holsten med samme dampskib, der havde bragt deputationen.

- Som rygte hørte jeg - at der blev truffet nogle forberedelser til ufortøvet at sende tropper med dampskib til Rendsborg (over Eckernførde). Jeg tror også, at det allerede forlød i forgemakket, at mandskabsindkaldelser var udgåede den $20 \mathrm{de}$, men at der iøvrigt herskede en del forvirring i alle retninger. (22 $^{22}$

Han fortæller videre, at han havde truffet aftale med Harbou om foreløbig at ansætte ham som adjudant (men ikke om Harbous samtale med ham under statsrådsmødet).

"Såsnart ministeriet var indsat, " fortsætter han, »begav jeg mig til Amalienborg - Jeg fik her at vide, at mandskabet var indkaldt til linjebataljonerne $i$ Danmark, og at der var taget nogle foreløbige forberedelser til at samle det $\mathrm{i}$ København tilstedeværende mandskab, omtrent 1600 mand, og sende dem pr. dampskib til Eckernførde for derfra at marchere på Rendsborg. Der lod sig 
ikke regne på, at de kunne blive færdig til indskibning førend tidlig om morgenen den 23. og ikke være i Eckernførde førend 24. morgen - Ved at tage mandskabet fra de københavnske bataljoner, blev disses kadrer bragt i uorden og mindre skikkede til at udfyldes med det indkaldte mandskab. Ved den hovedkulds ekspedition blev meget forstyrret for et usikkert resultat; de forholdsregler, som var taget dertil, var ufuldstændige. Jeg opgav derfor denne mere drømte end betænkte ekspedition, der måske, om den var blevet forberedt den 20. og sat i værk den 21. endnu kunne have haft udsigt til at lykkes.«

Som en slags undskyldning(?) fremfører Tscherning, at han endnu ikke d. 22. formelt havde overtaget krigsministeriet, men kun havde kongens mundtlige udnævnelse. Først den næste dag forelå en kgl. parolebefaling. ${ }^{23}$

Mens oberst N. P. Jensen i bogen »Den første slesvigske Krig « (1898) medgiver Tscherning, at opgivelsen af ekspeditionen var $"$ med rette ${ }^{24}$ er generalstabens arbejde mere kritisk, idet den konkluderer, efter at have nævnt, at Tscherning bebrejder den tidligere regering, at ekspeditionen ikke var blevet afsendt $\mathrm{d}$. 20. eller 21.: »Efter dette måtte man altså have ret til at forvente, at Tscherning ville handle og handle øjeblikkeligt. Men dette skete ikke $-\ll .{ }^{25}$

$\mathrm{Nu}$ er forholdet jo det, at Tscherning nedskrev sine erindringer 20 år efter begivenheden, altså i 1868, og at de først blev udgivet af hans slægtninge efter hans død. Om der har foreligget samtidsnotater vides ikke. Harbous erindringer udkom i 1870, altså endnu mens Tscherning levede (han døde i 1874), men der ses ikke at foreligge nogen indsigelse fra hans side.

Det kan jo da i hvert fald kun opfattes som en efterrationalisering fra Tschernings side, når han lader forstå, at han stoppede ekspeditionen d. 22. marts, fordi den ikke ville kunne nå at forhindre indtagelsen d. 24. Derom kunne han umuligt vide noget på daværende tidspunkt!

Der er imidlertid endnu et hovedvidne, hvis beretning om tildragelserne er trykt og offentliggjort allerede året efter.

Det er artillerikaptajn A. W. Dinesen, som i 1849 udsendte bogen: "Den slesvigske krig i 1848. Ved en officer af armeen. « Selv om den altså var anonymt udgivet, var det almindelig bekendt - og misbilliget $i$ visse kredse - at det var ham, der var forfatteren.

"Vi kunne ikke tilbageholde et udbrud af dyb smerte, « hedder det, »ved at bemærke, at man fra dansk side ikke almindeligt betragtede vigtigheden af Rendsborg for den danske sag på samme måde, som insurgenterne betragtede den for deres sag, og at man intet vovede for at komme $i$ besiddelse af fæstningen, forinden insurrektionen havde bemægtiget sig den, og de vaklende tropper var blevet forførte. For os stod det dengang lige så klart, som det står nu, at Danmarks skæbne var afhængig af, om Rendsborg blev taget eller ikke taget. 
Dette kunne have været udført med Københavns og citadellets infanterigarnison, henved 2000 mand eller blot en større part af den, såsom 12 til 1400 mand og et batteri.«I en fodnote tilføjer han: "Hertil behøvede man selvfølgelig kun at have medført et forholdsvist antal befalings- og underbefalingsmænd, for ikke at blotte de i garnisonsdepotet forblevne kadrer, som måtte optage deres indkaldte frifolk, der senere ville være at oversende som en forstærkning til oprørets fuldstændige undertrykkelse.

Insurrektionen ville derved have været kvalt i fødslen, og Tysklands navnlig Prøjsens indblanding, der først viste sig så gemytlig som et mæglingsforsøg, ville da have fået et ganske andet udseende for de europæiske kabinetter og for hele verden. Den ville da have haft at begynde med belejringen af en fæstning, hvortil en belejringspark ville have været fornøden, kort sagt; der ville, såvel i politikken som i den praktiske udførelse, have vist sig så betydelige misligheder og vanskeligheder, at det er højst sandsynligt, at Prøjsen ville være veget tilbage for det ansvar, der fulgte med et sådant skridt. ${ }^{26}$

\section{Støtte fra Tyskland}

Det har tidligere været en almindelig opfattelse, at Prøjsen allerede før oprettelsen af den provisoriske regering og indtagelsen af Rendsborg havde lovet militær støtte. Det hedder f.eks. hos Frits Holst og Axel Larsen $i$ »Felttogene i vore første frihedsår $\aleph^{27}$ at »lejligheden til en krig blev - greben med begærlighed, « så at "hertugen ikke behøvede at bruge synderlig overtalelse for at få Preussens konge til at gå ind på hans planer«, og »at d. 24. marts - lod kongen hertugen tilstille et brev, hvori han åbenlyst tilsagde oprørerne sin hjælp -

Som det fremgår af det tidligere refererede, er dette jo ikke rigtigt. Ingen vidste i Berlin noget om oprøret, og kongens ord om, at whertugdømmerne ikke trues af nogen alvorlig fare«, ville da også have virket helt grotesk, hvis det havde været tilfældet!

Først d. 26. marts, da man havde fået efterretning om den provisoriske regerings dannelse og oprørets udbrud, befalede den prøjsiske konge, at der skulle koncentreres et korps ved Havelberg, og d. 31. blev det bestemt, at 6 gardebataljoner og 6 kanoner skulle transporteres til Rendsborg. ${ }^{28}$

Takket være en hurtig offentliggørelse af kongens svar, opstod der ganske vist i København det rygte d. 27. marts, at den prøjsiske hær var rykket ind i Holsten, men den første og eneste soldat, der havde meldt sig i Rendsborg på denne dato, var den førnæunte fætter til hertugen!

Hirschfeld er af den opfattelse, at hvis der d. 22. om morgenen var blevet givet befaling om undsætning og de disponible tropper indskibet samme aften, 
ville »de par prøjsiske garde-regimenter Frantz og Alexander sammen med det 20. regiment ikke have kunnet udrette noget ved indtagelse af fæstningen. $\kappa^{29}$

Selv om Hirschfeld jo ikke netop er uvildig i denne sag, er der vel ingen grund til at afvise hans ræsonnement. For ganske vist var den prøjsiske konge Frederik Vilhelm uberegnelig, men det er svært at forestille sig, at han ville have sat sine tropper i bevægelse i forbindelse med en aktion, som nærmest havde karakter af en vagtafløsning.

Af andre grunde ville det militære sammenstød nok have været uundgåeligt, men i så fald var det jo ikke begyndt med et sådant handicap til danskerne, som tabet af en stærk grænsefæstning m.v. måtte være.

Historikeren må naturligvis altid tage et vist forbehold overfor sætninger, der begynder med spørgeordet $»$ hvis«. På den anden side er det ofte fristende og ikke altid omsonst at underkaste et begivenhedsforløb en undersøgelse, der munder ud i betragtninger over, hvordan det kunne være gået. ${ }^{30}$

\section{NOTER OG HENVISNINGER}

1. Fædrelandet 8.3.1848.

2. N. P. Jensen: Den første slesvigske krig, 1898, s. 18-28 (breve til general Ewald), jvfr. Dansk biografisk leksikon 3. udg. bd. 12, s. 511 .

3. se fodnote hos N. P. Jensen op.cit. 1898 s. 18.

4. Af Anthon Frederik Tschernings efterladte Papirer I-III, 1876-78 s. 265.

5. Holger Hjelholt: Om dannelsen af den provisoriske Regering, SJy Årb 1937, s. 3.

6. Otto Fock: Schleswig-Holsteinische Erinnerungen, Leipzig 1863 s. 59.

7. Joh. H. Gebauer: Christian August, Stuttg. 1910 s. 215.

8. Af Eleonore Christine Tschernings efterladte Papirer (Memoirer og Breve, VIII, 1908) s. 198 samt Tschernings efterladte Papirer note s. 266.

9. J. G. Droysen og K. Samwer: Die Herzogthümer Schleswig-Holstein und das Königreich Dänemark, 1850 s. 247.

10. Johs. Harbou: Nogle Erindringer nærmest med Hensyn til Krigen 1848-50, 1870 s. 10.

11. Harald Jørgensen (ed.): Statsrådets forhandlinger, 1. bind, 24. januar-15. november 1848, 1954 s. 116-123. Referenten har skrevet "geheime«, men udstreget det!

12. Harbou, 1870 , s. 11.

13. Af Tschernings efterladte Papirer s. 267.

14. Joh. H. Gebauer: Christian August, 1910 s. 12. Forfatteren har haft adgang til utrykt materiale.

15. Aug. Sach: Geschichte der Stadt Schleswig, 1875 s. 305f. Se også Holger Hjelholt i SJy Årb 1937 og H. Neerbek i SJy Årb 1956.

16. Vilh. Hirschfeld: Historische Rückblicke, Hamburg 1873-74 s. 43 f.

17. ibid. s. 45.

18. Fock, 1863 s. 79.

A. Hansen: Der 24. März, Schleswig 1873 s. 30.

19. Rømelings relation er aftrykt i $O$. Vaupell: Læsseres Levned og Aktstykker til Krigen 1848-50, 1895 s. 37.

20. Gebauer, 1910 s. 364.

21. ibid. s. $217 \mathrm{f}$.

22. Tschernings efterladte Papirer s. 268.

23. ibid. s. 272. 
24. N. P. Jensen, 1898 s. 84.

25. Den dansk-tydske Krig i Aarene 1848-50 udg. af Generalstaben, $1867-87$ s. 49.

26. A. W. Dinesen: Den slesvigske krig i 1848. Ved en officer af armeen, 1849 s. 3.

27. Frits Holst og Axel Larsen: Felttogene i vore forste frihedsår, 1888 s. 55.

28. N. P. Jensen: Den første slesvigske krig, 1898 s. 107.

29. Hirschfeld, 1873-74 s. 43.

30. (supplerende oplysninger): a) Der var tilstrakkelig skibskapacitet til overførsel 22.3. Planmæssig sejltid: ca. 12 timer. (H. Degenkolv: Opt. vedr. den da. flådes skibe i sidste årh. (1906) s. 48, 50, 52, 54. også: Jørgen Barfod: Flåden (i Tøjhusmuseets bog om treårskrigen (1945) 1. bd. s. 484. b) Strækningen Eckernførde-Rendsborg (subs. Kiel-R.) kan tilbagelægges som dagsmarch (Trap: Hertugd. Schles. 1864, s. 61. Lærebog f. Menige v. Fodfolksreg. (Udg. 1899) s. 192. 